\title{
A ruptura da idéíla de envelhecimento bem-sucedidio e as digressões urbanas: algumas reflexões
}

\author{
| Breaking the idea of suceessful aging and urban digressions: some reflexions
}

Pedro Rieardo da Cunha Nóbrega

Mestre em Desenvolvimento e Meio Ambiente pela Universidade Federal de Pernambuco (UFPE)

Doutorando em Geografia (Geografia Humana) pela Universidade de São Paulo (USP)

O urbano se apresenta como um texto de grande complexidade, complexo se olhado de longe e por cima e ainda mais complexo se olhado de baixo e por dentro ${ }^{2}$. Os ajustes de escalas que ajudam a pensar os dilemas e trajetórias da reprodução da vida em sociedade chegam até o momento em que o cotidiano e a vida cotidiana ${ }^{4,5}$ aparecem como o local fundamental e possível para analisar as sutilezas de um processo que se realiza em diversos níveis, mas, que ganham sentido no lugar de realização da vida e por isso saem daí as possibilidades de ajustar conceitos e ressaltar a força das digressões urbanas ${ }^{7}$. Os emaranhados, fios, conexões da realização da vida em sociedade e conseqüentemente os processos de reprodução do espaço assumem perspectivas múltiplas, principalmente quando se pensa que o mundo moderno se apresenta, entre outras coisas, como fragmentado, desvinculado de comprometimentos éticos e completamente apropriado pelo processo de reprodução do capital ${ }^{4}$.

Neste contexto, o envelhecimento humano tomado como foco de análise das questões urbanas contemporâneas faz emergir a velhice como categoria de análise, mas que sob nenhuma hipótese está desvinculada dos pressupostos econômicos, sociais e históricos ${ }^{1}$. Por isso, a velhice se apresenta não como uma unidade, mas, como um multipolaridade de questões que se aglutinam através de um prisma analítico ${ }^{3}$ " Não há dúvida de que a velhice se tornou mais visível nas últimas décadas, como é certo também, que um novo padrão de conduta desta parcela da população, está sendo criado"1 e com isso os países "vêem surgir na velhice um novo problema social comum, e conseqüentemente, vêm enfrentando as novas configurações e relações intergeracionais como algo 'normal'" 1.

A vida cotidiana e os processos de reprodução do tecido urbano na contemporaneidade, principalmente no que tange à velhice e aos processos de envelhecimento da população estão completamente associados ao processo de reprodução do capital e com isso surge, inexoravelmente, uma consciência de classe em detrimento de um conflito geracional. Há uma representação da velhice que foi historicamente construída baseada em um projeto de sociedade que associa a mendicância e a criminalidade a grupos sociais minoritários, entre eles os idosos, os 
deficientes, os malandros, os drogados, as prostitutas, entre outros.

Assim, mesmo antes de ser considerada um problema social, a velhice assumiu a forma de um problema humanitário, objeto da filantropia e reflexo da lógica de exclusão da acumulação capitalista ${ }^{1}$.

A vida realizada com moldes urbanos, o projeto de sociedade que se constrói diariamente associada ao processo de reprodução do capital e as imposições por manter a produtividade e o desenvolvimento são associados para construir uma interpretação do mundo capaz de capturar todos os movimentos da vida cotidiana com o objetivo de mascarar as debilidades e projetar as potencialidades. É nesse contexto que vejo emergir a partir da gerontologia a idéia de envelhecimento bem-sucedido 1,3 .

No contexto da crise de acumulação do capital, uma parcela dos estudos sobre o envelhecimento humano, e as implicações sociais dessa condição, parece apontar para uma lógica cada vez mais cruel que tem como base: classificar e hierarquizar os tipos de seres humanos. Parece-me que uma das versões é a criação de uma "nova moeda", neste caso a saúde, ela entra como elemento necessário para a reprodução do modo de produção capitalista, que cada vez mais necessita da força de trabalho capacitada e experiente. A partir daí pode-se aproveitar ao máximo a potencialidade produtiva dos indivíduos, que apesar de serem idosos, podem e necessitam, para alimentar as engrenagens do sistema, gerar lucro e auxiliar na produção de mais-valia, de uma sociedade que ainda se mantém industrial.

Mesmo os especialistas que ajudaram a desenvolver a idéia de envelhecimento bem-sucedido ao definirem o conceito têm constrangimentos, assumindo a dificuldade existente em classificar o que é exatamente esse envelhecimento bem-sucedido.

A definição de uma velhice bem-sucedida é uma coisa muito difícil, pois ela apresenta o problema de seus indicadores ou de seus critérios, que são numerosos $e$ às vezes fortemente interdependentes. A abordagem "multicritério" é a mais freqüente. Os critérios mais freqüentemente lembrados pelos pesquisadores são a longevidade, a saúde biológica, a saúde mental, a eficácia intelectual, a competência social, a produtividade, o controle pessoal ou a conservação da autonomia e o bem-estar subjetivo ${ }^{3}$.

Aparentemente, a constituição de uma velhice e um envelhecimento bem-sucedido está baseada em uma leitura clara de um mundo construído a partir de classes sociais, em que apenas aqueles que têm condições de acumulação é que podem participar deste grupo seleto. Em uma sociedade como a brasileira, basear as análises a partir dos parâmetros estabelecidos para um envelhecimento bem-sucedido é no mínimo criminoso.

Ao mesmo tempo em que o estado não participa minimamente da construção de um modelo de uma sociedade mais justa, menos desigual, os agentes hegemônicos que são, dentre outros, responsáveis pelo sentido da reprodução da vida social cada vez mais eliminam a possibilidade de estabelecer lógicas mais horizontais e menos desiguais, o que toca diretamente na qualidade de vida e na possibilidade de participação sociais dos idosos no cenário público. Não aqui se apela por um modelo welfarista, mas, entende-se que a ação política, na verdade, a substituição da política pelos instrumentos econômicos na mediação dos contextos sociais, inibe e impossibilita, em quase toda a totalidade do globo, que exista uma vida que caminhe para uma velhice bem-sucedida para todos os indivíduos idosos.

Menos do que um envelhecimento bem-sucedido, espera-se que minimamente se possam construir práticas urbanas e projetos de saúde coletiva, que garantam o direito à cidade 5 para todos os indivíduos, sem que necessariamente estejamos pensando em um desenho universal ou uma cidade do pensamento único, mais que isso, pensasse uma 
cidade que abarque a polissemia. Para tanto, não é possível desconsiderar o conjunto das digressões urbanas $^{6}$ que estão diretamente relacionadas com a necessidade de buscar espaços que garantam as particularidades de cada grupo social.

(...) digressão significa desvio de rumo ou assunto. Pode significar também um subterfúgio ou uma evasiva, ou ainda um recurso literário utilizado com o fim de esclarecer ou criticar o assunto em questão. [... as] digressões juntas pretendem ampliar como subterfúgio (mas jamais como evasiva), às vezes desviando propositadamente de rumo (mais jamais fugindo do assunto), as discussões precedentes sobre o espaço público na cidade contemporânea ${ }^{6}$.

É esse lugar e essa propriedade se fugir das imposições que geram as impossibilidades de reprodução da vida que a noção de um envelhecimento bemsucedido é posta em xeque. A reprodução da vida, a materialização das necessidades e a constituição imposta pela lógica de reprodução do capital inviabilizam qualquer possibilidade de levar a sério uma perspectiva de análise que tente obscurecer a leitura da realidade.

\section{Referências}

1. Coutrim RME. A velhice Invisível: O cotidiano de idosos que trabalham nas ruas de Belo Horizonte. São Paulo: AnnaBlume, 2010.

2. Certeau M. A invenção do cotidiano: artes de fazer. $7^{\mathrm{a}}$. ed. Petrópolis: Vozes, 2002.

3. Fontaine R. Psicologia do Envelhecimento. São Paulo: Loyola, 2010.

4. Lefebvre H. A vida cotidiana no mundo moderno. São Paulo: Ática, 1991.

5. Lefebvre H. O direito à cidade. São Paulo: Centauro, 2001.

6. Serpa A. O espaço público na cidade contemporânea. São Paulo: Contexto, 2009. 